\title{
Nitrogênio e fósforo no crescimento de plantas de ginseng brasileiro [Pfaffia glomerata(Spreng.) Pedersen] cultivadas in vitro $^{I}$
}

\author{
Nitrogen and phosphorus on growth of brazilian ginseng [Pfaffia \\ glomerata (Spreng.) Pedersen] in vitro cultured plants
}

\author{
Denise Russowski $^{2}$ Fernando Teixeira Nicoloso ${ }^{3}$
}

RESUMO

\begin{abstract}
O ginseng brasileiro [Pfaffia glomerata (Spreng.) Pedersen] apresenta propriedades medicinais marcantes e, por isso, atualmente, é largamente explorado de forma extrativista, tanto por parte dos coletores de ervas como pela indústria farmacêutica. Este trabalho objetivou caracterizar o efeito da variação isolada da concentração de $N$ e P do meio MS no crescimento de plantas de P. glomerata cultivadas in vitro. Segmentos nodais de $1,0 \mathrm{~cm}$ de comprimento e sem folhas, de plantas já estabelecidas in vitro, foram cultivados em meio MS contendo cinco concentrações (0, 25, 50, 100 e $150 \%$ da concentração padrão do meio de cultura MS) de nitrogênio ou fósforo. Aos 15 dias após a inoculação (DAI), o número de raizes e o percentual de enraizamento são maiores na concentração de $N$ e P equivalentes a $50 \%$ daquela do meio de cultura MS. Aos 40 DAI, o crescimento em altura das brotações, número de segmentos nodais, indice de área foliar, número de folhas, matéria seca de raízes, da parte aérea e total da planta é maior na concentração de $N$ e P, em média, próxima a $80 \%$ daquela do meio de cultura MS.
\end{abstract}

Palavras-chave: micropropagação, macronutrientes, cultura de tecidos, Amaranthaceae.

\section{ABSTRACT}

Brazilian ginseng [Pfaffia glomerata (Spreng.) Pedersen] has expressionable medicinal properties, and therefore, nowadays it is extensively exploited either by the herb collectors as well as the pharmaceutical industry. The aim of this work was to characterize the effect of $\mathrm{N}$ and $\mathrm{P}$ concentrations from the MS medium on growth of $\boldsymbol{P}$. glomerata in vitro cultured plants. 1-node segment without leaves, from in vitro cultivated plants, were grown on five levels $(0,25,50$, 100 , and $150 \%$ of the strength of the MS medium) of $\mathrm{N}$ and $\mathrm{P}$. After 15 days of inoculation, root number and rooting percentage are greater on $\mathrm{N}$ and $\mathrm{P}$ levels of the MS medium with $50 \%$ strength. After 40 days of inoculation, growth, based on sprout height, number of nodal segments per plant, leave area index per plant, number of leaves per plant, dry weight of aerial parts, roots and of the whole plant, is greater when the $\mathrm{N}$ and P levels of the MS medium is near to $80 \%$ strength.

Key words: micropropagation, macronutrient, tissue culture, Amaranthaceae.

\section{INTRODUÇÃO}

As raízes de Pfaffia glomerata (Spreng.) Pedersen, bem como de Pfaffia paniculata (Mart.) O. Kuntze, ambas pertencentes à família Amaranthaceae e conhecidas como ginseng brasileiro, são de grande interesse comercial na forma de fito-medicamentos e suplementos alimentares, devido aos seus usos populares como antitumorais, antidiabetes e tônicos afrodisíacos. Em razão disso, tem ocorrido uma intensa exploração predatória das reservas naturais destas

${ }^{1}$ Parte da Dissertação de Mestrado apresentada pelo $1^{\circ}$ autor ao Programa de Pós-graduação em Agronomia, Centro de Ciências Rurais (CCR), Universidade Federal de Santa Maria (UFSM), Santa Maria, RS.

${ }^{2}$ Bióloga, Ms., Professor Substituto do Departamento de Biologia, Centro de Ciências Naturais e Exatas (CCNE), UFSM, Santa Maria, RS. E-mail: rusden@terra.com.br.

${ }^{3}$ Engenheiro Agrônomo, Doutor, Professor Adjunto do Departamento de Biologia, CCNE, UFSM, Campus Universitário Camobi. 97.105-900. Santa Maria, RS. E-mail: nicoloso@base.ufsm.br. Autor para correspondência. 
espécies, portanto justificando que sejam elaborados planos de manejo ou projetos de cultivo (MONTANARI et al., 1999).

Devido à propagação vegetativa da $\boldsymbol{P}$. glomerata via estaquia ser fisiologicamente viável, porém tecnicamente de baixo rendimento (NICOLOSO et al., 1999; NICOLOSO et al., 2001a), NICOLOSO et al. (2001b) desenvolveram um protocolo altamente reproduzível para a micropropagação desta espécie onde, a partir de um único segmento nodal, foi possível obter 15.000 plantas dentro de um período de seis meses.

O crescimento das culturas de células e tecidos vegetais in vitro depende em parte da otimização da concentração de três grupos de componentes do meio de cultura, a saber: os fitoreguladores, as substâncias orgânicas e os nutrientes minerais. Para MORARD \& HENRY (1998) e MORARD et al. (1999), em alguns casos, a alteração da composição mineral parece ser a que mais traz benefícios. Em P. glomerata foi observado que a concentração padrão dos macronutrientes do meio MS (MURASHIGE \& SKOOG, 1962) e a ausência de carvão ativado favoreceram o crescimento das plântulas (NICOLOSO et al., 2001b).

Aos 60 dias de cultivo de explantes de bananeira cv. Prata Anã, DINIZ et al. (1997) observaram que as quantidades de nutrientes totais absorvidas pelos propágulos seguiram uma ordem diferente, como o segue: $\mathrm{K}>\mathrm{N}>\mathrm{Ca} \geq \mathrm{P}>\mathrm{Mg} \cong \mathrm{S}$, além disso, o $\mathrm{P}$ foi o nutriente absorvido mais rapidamente, sendo extraído $75 \%$ do $\mathrm{P}$ inicial do meio, nos primeiros 30 dias. Segundo BARBAS et al. (1993), a cessação da produção da biomassa no híbrido Juglans nigra $\mathrm{x}$ Juglans regia foi precedida por um decréscimo no nível de $\mathrm{P}$ nos tecidos, enquanto nenhuma grande alteração ocorreu nos teores de N, K, Mg, Fe e Ca. Estes resultados levaram NICOLOSO et al. (2001b) a sugerir que a resposta linear positiva da $\boldsymbol{P}$. glomerata cultivada in vitro à variação conjunta da concentração de todos macronutrientes do meio MS deveu-se, possivelmente, ao rápido esgotamento dos nutrientes $\mathrm{N}, \mathrm{P}$ e K do meio de cultivo, devido a sua alta taxa de crescimento.

O presente trabalho objetivou caracterizar o efeito da variação isolada da concentração de $\mathrm{N}$ e $\mathrm{P}$ do meio MS no crescimento de plantas de $\boldsymbol{P}$. glomerata cultivadas in vitro.

\section{MATERIALEMÉTODOS}

O experimento foi desenvolvido no Laboratório de Biotecnologia Vegetal pertencente ao Departamento de Biologia da Universidade Federal de Santa Maria(UFSM), RS.
Plantas assépticas, advindas de cultura de segmentos nodais (segundo o protocolo descrito por NICOLOSO et al., 2001b), com 35 dias de idade, cultivadas em meio MS (MURASHIGE \& SKOOG, 1962) completo, suplementado com $30 \mathrm{~g} \mathrm{~L}^{-1}$ de sacarose e na ausência de fitoreguladores, com pelo menos uma brotação possuindo cinco segmentos nodais, foram utilizadas como fonte de explantes. Segmentos nodais de 1,0cm de comprimento contendo duas gemas no nó e sem folhas, obtidos apenas da maior brotação, consistiram os explantes (excluindo-se segmentos nodais apicais).

Realizaram-se 10 tratamentos, que consistiram de cinco concentrações $(0,25,50,100$ e $150 \%$ da concentração padrão do meio de cultura MS) de nitrogênio e de fósforo, variando-as isoladamente. Os demais nutrientes do meio de cultura permaneceram constantes na concentração original do meio de cultura MS. Além disso, não se alterou a distribuição entre as fontes de $\mathrm{N}^{-\mathrm{NO}_{3}}{ }^{-}$e $\mathrm{N}-\mathrm{NH}_{4}{ }^{+}$em todos tratamentos.

$\mathrm{O}$ delineamento experimental foi o inteiramente casualizado com 25 repetições por tratamento. A parcela experimental consistiu de um tubo de ensaio $\left(20 \mathrm{~cm}\right.$ altura $\times 2 \mathrm{~cm} \varnothing$, volume interno $\left.=125,7 \mathrm{~cm}^{3}\right)$ contendo $10 \mathrm{~mL}$ de meio MS, geleificado com $0,6 \%$ de ágar, suplementado com $30 \mathrm{~g} \mathrm{~L}^{-1}$ de sacarose, e um segmento nodal. $\mathrm{O}$ pH do meio de cultivo foi ajustado para 5,8 antes da inclusão do ágar e da autoclavagem (1 atm, $\left.120^{\circ} \mathrm{C}, 15 \mathrm{~min}\right)$. $\mathrm{O}$ cultivo dos explantes foi realizado em câmara climatizada com temperatura de $25 \pm 2^{\circ} \mathrm{C}$ e fotoperíodo de $16 \mathrm{~h}$, sob intensidade luminosa de $35 \mu \mathrm{mol} \mathrm{m} \mathrm{m}^{-2} \mathrm{~s}^{-1}$ fornecida por lâmpadas fluorescentes extra luz do dia (Philips). Os recipientes de cultivo foram fechados com folha de papel alumínio e filme plástico de PVC.

Aos 15 dias após a inoculação (DAI), foram avaliados o número de raízes por planta e o percentual de enraizamento, e aos $40 \mathrm{DAI}$, foram avaliados o percentual de enraizamento, número médio de brotações por planta, altura média das brotações, número médio de segmentos nodais por planta, índice de área foliar por planta, aérea foliar unitária, número médio de folhas por planta e a matéria seca da parte aérea, matéria seca das raízes e matéria seca total por planta, bem como a relação entre a matéria seca da parte aérea e das raízes. A determinação do índice de área foliar foi realizada através da análise computadorizada pelo software SITTER 1.0 para Windows (desenvolvido pelo Departamento de Engenharia Rural da UFSM, acoplado a uma mesa digitalizadora).

As análises estatísticas foram executadas pelo software estatístico SOC (Software Científico- 
NTIA/EMBRAPA) em nível de 5\% de probabilidade de erro.

\section{RESULTADOS E DISCUSSÃO}

Independente da variação da concentração de $\mathrm{N}$ e $\mathrm{P}$, as raízes produzidas emergiram na base dos explantes aos 10 dias após a inoculação (DAI), processo que ocorreu logo após o início do desenvolvimento das primeiras folhas. Entretanto, o desenvolvimento da parte aérea só ocorreu após um considerável crescimento das raízes, aos 13 DAI. Aos 15 DAI, o número de raízes por planta foi maior na concentração de $\mathrm{N}$ equivalente a $50 \%$ daquela do meio de cultura MS (Fi- gura 1a), enquanto a variação da concentração de $P$ não provocou nenhum efeito sobre esse parâmetro. Em Solanum tuberosum, SARKAR \& NAIK (1998) observaram que a redução até a quarta parte da concentração de $\mathrm{N}$ do meio MS proporcionou aumento no número de raízes por planta. Já NICOLOSO et al. (2001b) não constataram influência da variação conjunta de todos macronutrientes do meio MS no número de raízes de plantas de $\boldsymbol{P}$. glomerata aos 14 DAI.

O percentual de enraizamento aos $15 \mathrm{DAI}$ também foi maior na concentração de $50 \%$ de $\mathrm{N}$ do meio de cultura MS, obtendo-se em torno de $98 \%$ de enraizamento, não havendo efeito significativo para as concentrações de P estudadas (Figura 1b). Por outro

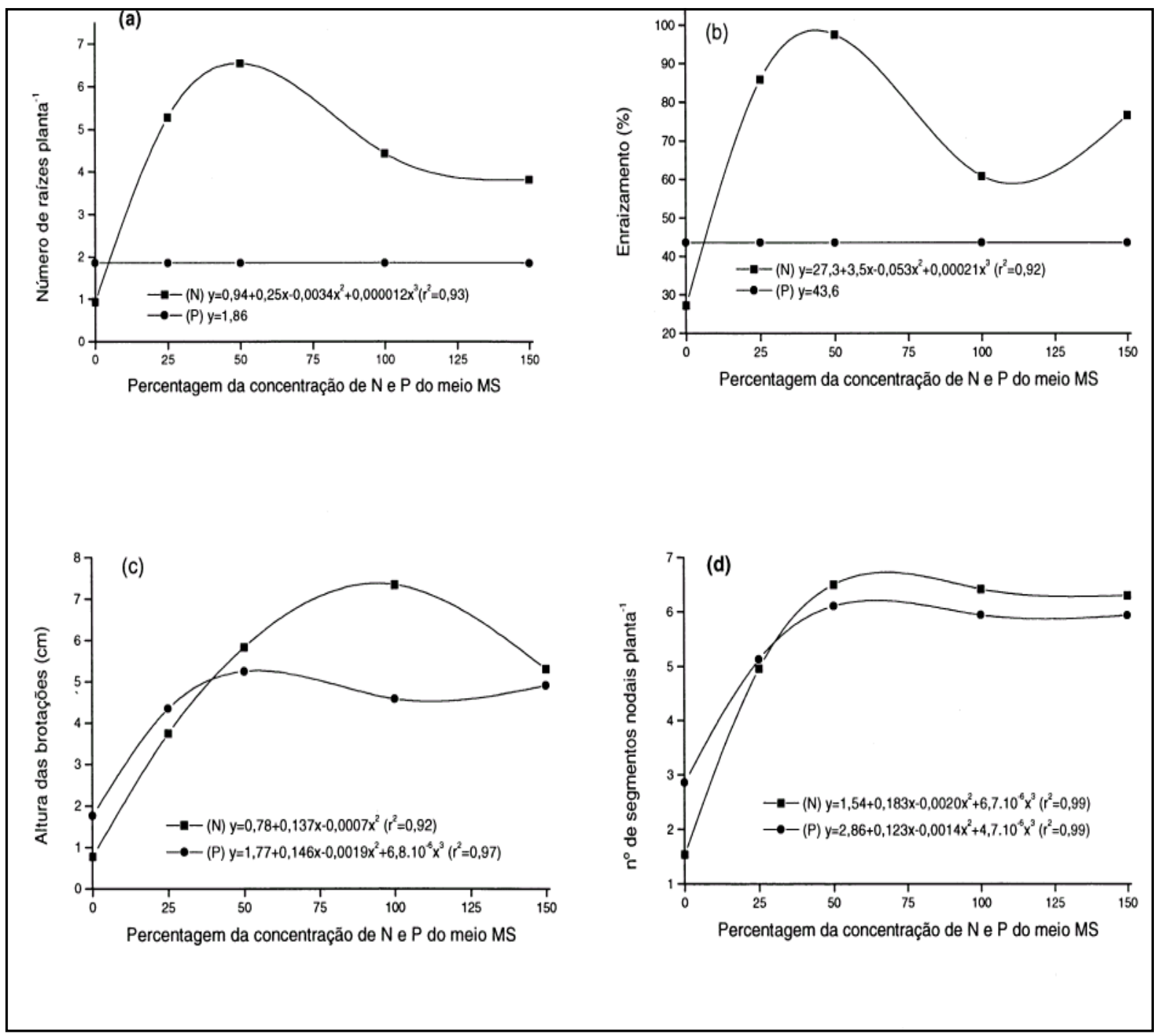

Figura 1 - Efeito da variação da concentração de nitrogênio e fósforo do meio de cultura MS no número de raízes (a) e no percentual de enraizamento (b) aos 15 dias após a inoculação (DAI), e aos 40 DAI, na altura das brotações (c) e no número de segmentos nodais por planta (d) de Pfaffia glomerata cultivada in vitro.

Ciência Rural, v. 33, n. 1, jan-fev, 2003. 
lado, aos 40 DAI, o enraizamento não foi alterado pela variação da concentração de ambos macronutrientes, cujas médias foram de $98,4 \%$ e $100 \%$, respectivamente, para o N e P. Estudos realizados por NICOLOSO et al. (2001b) mostram que a percentagem de enraizamento (91\%) da $\boldsymbol{P}$ glomerata não foi influenciada pela variação conjunta de todos macronutrientes do meio de cultura MS aos 14 DAI. Segundo LEIFERT et al. (1995), a redução da concentração de N pela metade da concentração do meio MS é um procedimento muito comum na indução de enraizamento. Estudos em Solanum tuberosum, por ZARRABEITIA et al. (1997), e em Syzygium alternifolium, por KHAN et al. (1999), também mostraram que a iniciação e o crescimento do sistema radicular foram maiores quando a concentração de $\mathrm{N}$ foi reduzida pela metade daquela do meio MS. Diferentemente do que ocorreu em $\boldsymbol{P}$. glomerata, a redução da concentração de P pela metade favoreceu o enraizamento de Albizia procera (KUMAR et al., 1998). $\mathrm{O}$ alto percentual de enraizamento obtido aos 40 DAI na ausência de $\mathrm{N}$ e $\mathrm{P}$ no meio de cultura MS, se deve ao fato da $\boldsymbol{P}$. glomerata enraizar com facilidade (NICOLOSO et al., 1999; NICOLOSO et al., 2001a).

O número de brotações por planta não variou pela modificação das concentrações de $\mathrm{N}$ e $\mathrm{P}$, cujas

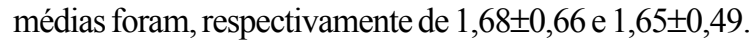
Estes resultados foram semelhantes aos encontrados por NICOLOSO et al. (2001b), demonstrando que a $\boldsymbol{P}$. glomerata não apresenta plasticidade quanto ao número de brotações formadas por explante de segmento nodal contendo um nó e duas gemas.

A altura das brotações (Figura 1c) apresentou ponto de máxima eficiência técnica estimada (PMET) à variação isolada de $\mathrm{N}$ e $\mathrm{P}$, respectivamente, de 100 e $60 \%$ daquela do meio de cultura MS. Para o número de segmentos nodais por plântula (Figura 1d), o PMET foi $65 \%$ da concentração do meio de cultura MS para ambos nutrientes. Em experimentos realizados por NICOLOSO et al. (2001b), estes parâmetros de crescimento responderam linearmente à variação conjunta de todos os macronutrientes do meio MS. A dose ideal de $\mathrm{N}$ para o crescimento da planta in vitro não depende apenas da espécie vegetal, mas também da cultivar. AVILA et al. (1998) observaram que das três cultivares de Solanum tuberosum analisadas, a cv. Spunta apresentou o maior comprimento das brotações, número de segmentos nodais e matéria seca quando a concentração de $\mathrm{N}$ foi de $50 \%$, fato que os autores atribuíram ao aumento da eficiência do uso do carbono.

O índice de área foliar por planta (Figura 2a) apresentou resposta cúbica à variação da concentração de $\mathrm{N}$ e $\mathrm{P}$ no meio, sendo as maiores respostas em $150 \%$ da concentração do meio de cultura MS. Entre-

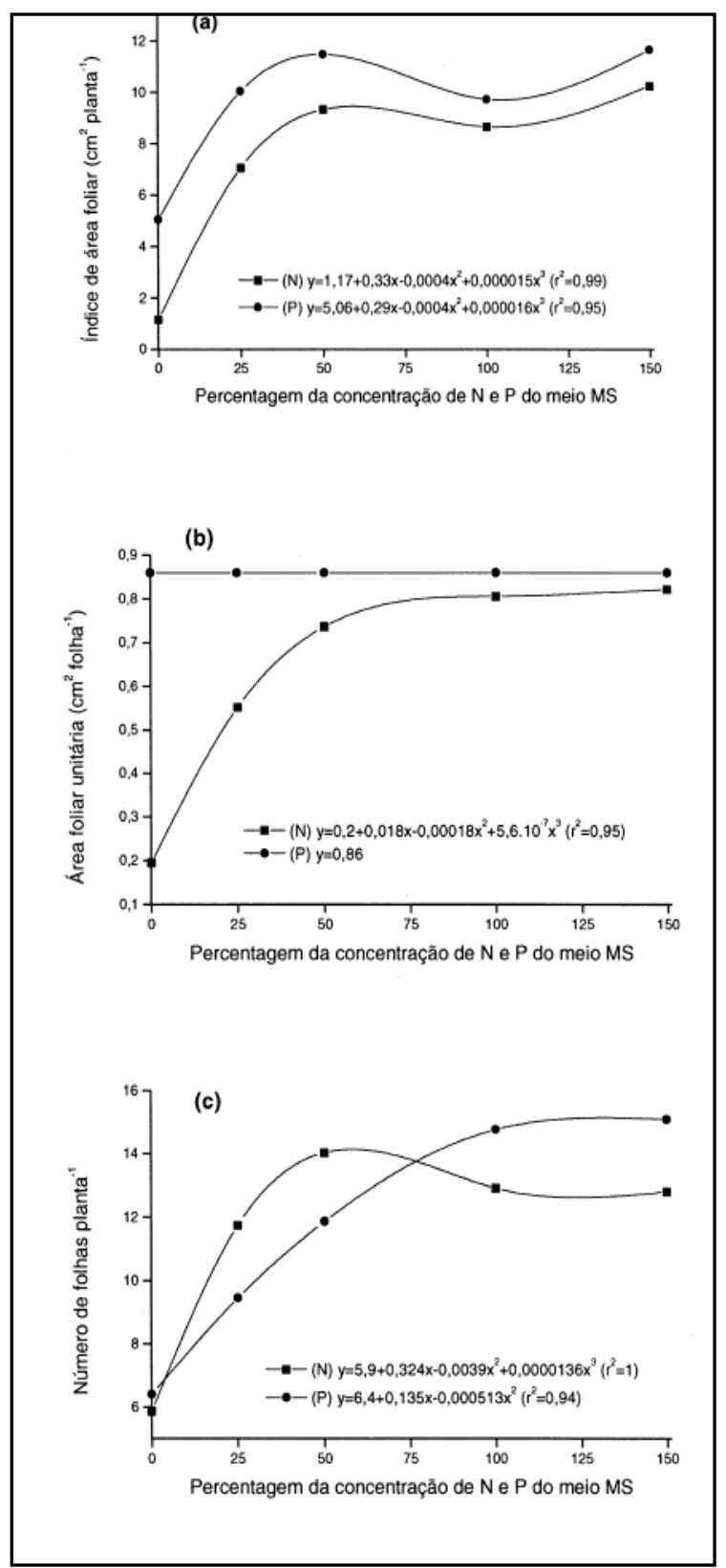

Figura 2 - Efeito da variação da concentração de nitrogênio e fósforo do meio de cultura MS no índice de área foliar (a), área foliar unitária (b) e número de folhas por planta (c) de Pfaffia glomerata cultivada in vitro aos 40 dias após a inoculação.

tanto, valores próximos a $50 \%$ proporcionaram respostas bastante próximas daquela obtidas em $150 \%$. Já a área foliar unitária (Figura 2b), respondeu apenas à variação do N, sendo maior na concentração de $150 \%$ daquela do meio de cultura MS. A resposta à variação da concentração de $\mathrm{N}$ e $\mathrm{P}$ no número de folhas por planta (Figura 2c) indica que, em função do PMET a esses nutrientes ser, respectivamente, $60 \%$ e $140 \%$ 
daquela do meio de cultura MS, o $\mathrm{N}$ afeta mais o crescimento da área foliar e o $\mathrm{P}$ o número de folhas emitidas por planta, embora ambos nutrientes sejam importantes nestes dois eventos fisiológicos, como constatado por FREDEEN et al. (1989), LYNCH et al. (1991), MARSCHNER (1995) e ERICSON (1995). Segundo MARSCHNER(1995), um baixo mas contínuo suprimento de $\mathrm{N}$ promove, inicialmente, a formação de raízes e o seu crescimento contínuo, além de induzir síntese de citocininas, que são importantes na expansão da área foliar.

A matéria seca de raízes apresentou PMET à variação isolada de $\mathrm{N}$ e $\mathrm{P}$, respectivamente, de $80 \% \mathrm{e}$ $85 \%$ da concentração do meio de cultura MS (Figura 3a). NICOLOSO et al. (2001), variando conjuntamente a concentração de todos macronutrientes, não observaram alteração na matéria seca de raízes de $\boldsymbol{P}$. glomerata. Já SARKAR \& NAIK (1998), alterando isoladamente a concentração de $\mathrm{N}$, verificaram que a matéria seca de raízes de Solanum tuberosum diminuiu pelo decréscimo da concentração de N de 100\% para 75\%. Para LEIFERT et al. (1995), a concentração de $\mathrm{P}$ do meio MS foi muito baixa para sustentar o crescimento normal de plantas de Hemerocallis, Iris e Delphinium.

Semelhantemente às respostas observadas na matéria seca de raízes, a matéria seca da parte aérea respondeu à variação da concentração de $\mathrm{N}$ e $\mathrm{P}$ no meio, com PMET, respectivamente, de 80 e $50 \%$ daquela do meio de cultura MS (Figura 3b). Considerando o comportamento da altura das brotações, número de segmentos nodais por planta, índice de área foliar por planta, área foliar unitária e o número de folhas por

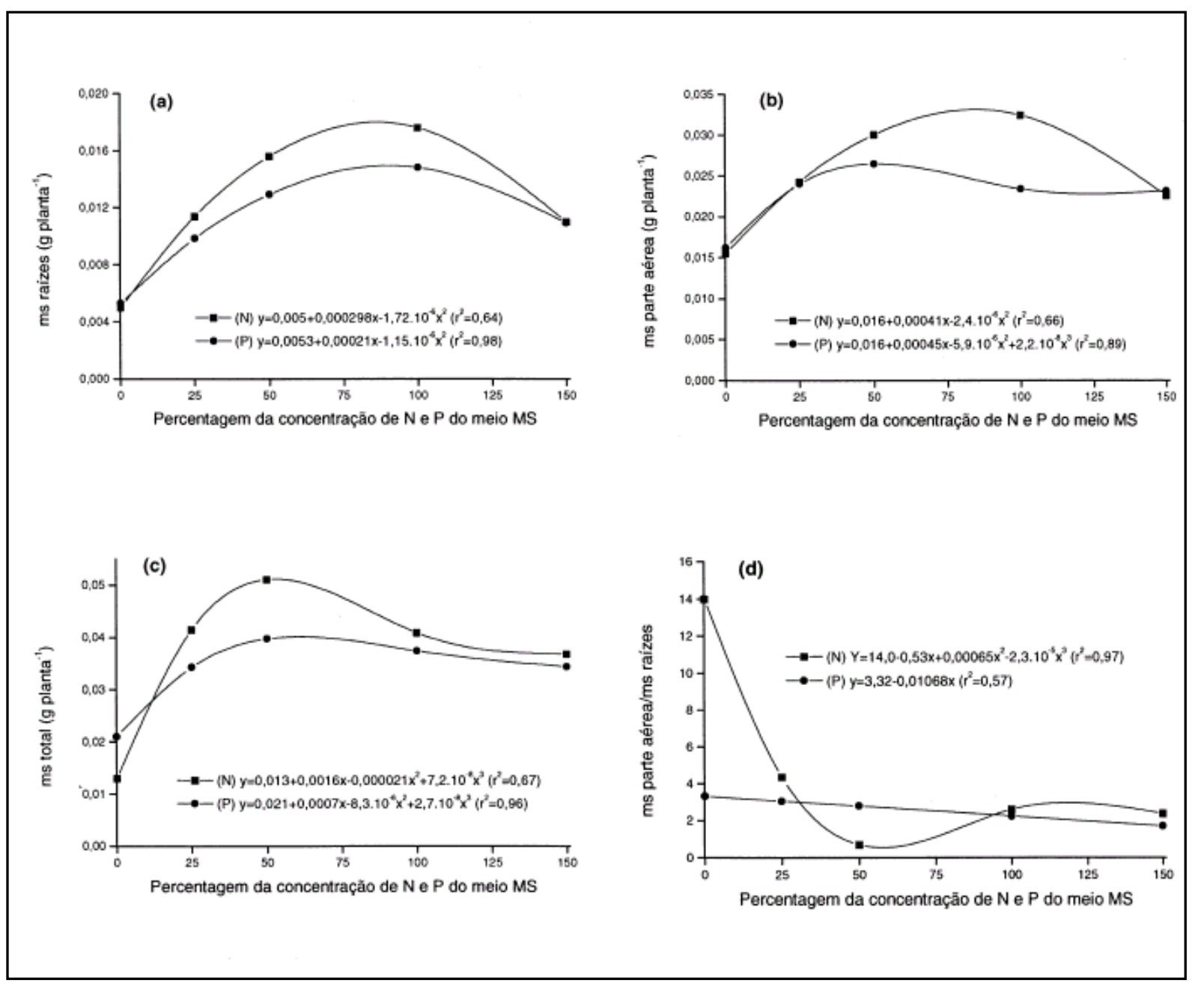

Figura 3 - Efeito da variação da concentração de nitrogênio e fósforo do meio de cultura MS na matéria seca das raízes (a), matéria seca da parte aérea (b), matéria seca total (c) e na relação entre a matéria seca da parte aérea e das raízes (d) por planta de Pfaffia glomerata cultivada in vitro aos 40 dias após a inoculação.

Ciência Rural, v. 33, n. 1, jan-fev, 2003. 
planta, a concentração de $\mathrm{N}$ e $\mathrm{P}$ que proporciona o melhor crescimento da parte aérea da P. glomerata fica entre 60 e $100 \%$ daquela do meio de cultura MS. Esses resultados corroboram as observações de MURASHIGE \& SKOOG(1962) eERICSON(1995) para outras espécies. Vários autores relataram respostas positivas na produção de biomassa pelo aumento isolado da concentração de $\mathrm{P}$ do meio de cultura. CURTIS et al. (1991) verificaram que doses crescentes de P no meio MS aumentaram a matéria seca de cultivos celulares de Papaver soniferum. ROBINS \& RATCLIFFE (1984) observaram em Humulus lupulus que, em concentrações entre 0 a $4 \mathrm{mM}$ de $\mathrm{P}$, houve aumento exponencial da matéria fresca, mantendo-se constante até $15 \mathrm{mM}$, quando começou a decrescer linear e drasticamente até $50 \mathrm{mM}$.

Os PMET da concentração de N e P na produção da matéria seca total da planta foram, respectivamente de, 60 e $70 \%$ daquela do meio de cultura MS (Figura 3c). Um fator que deve ser levado em consideração na escolha do nível adequado de um nutriente no meio de cultura, ou de outro fator qualquer, como a presença de um fitoregulador, é a sua relação com a distribuição da biomassa entre os órgãos da planta, haja visto que isto pode influenciar no processo de aclimatização das mudas micropropagadas (SERRET et al., 1997; SARTORI, 2000). Portanto, a relação entre a matéria seca da parte aérea e das raízes (RPAR) é de extrema valia, na qual se observou que os valores mais adequados foram de 80 e $100 \%$ da concentração do meio de cultura MS, respectivamente, para o $\mathrm{N}$ e $\mathrm{P}$ (Figura 3d). Em mudas de espécies florestais, a serem levadas a campo, valores de RPAR próximos a 2,0 são considerados ideais (DANIEL et al., 1997).

Considerando o aumento na altura das brotações (Figura 1c), número de segmentos nodais por planta (Figura 1d), índice de área foliar por planta (Figura 2a), número de folhas por planta (Figura 2c), matéria seca de raízes (Figura 3a), da parte área (Figura 3b) e total da planta (Figura 3c), devido ao aumento isolado da concentração de $\mathrm{N}$ e $\mathrm{P}$ do meio de cultura MS, fica demonstrado que o crescimento da $\boldsymbol{P}$. glomerata cultivada in vitro é limitado quando a concentração destes macronutrientes fica, em média, abaixo de $80 \%$ daquela do meio de cultura MS, fato que justifica em parte àquelas respostas encontradas por NICOLOSO et al. (2001b). Entretanto, estes resultados também sugerem que outros macronutrientes, além do $\mathrm{N}$ e do $\mathrm{P}$, como talvez o K, possam ter influência sobre a limitação do crescimento da $\boldsymbol{P}$. glomerata cultivada in vitro, caso contrário níveis de $\mathrm{N}$ e $\mathrm{P}$ acima de $80 \%$ da concentração do meio de cultura MS aumentariam o crescimento como um todo, fato observado por
NICOLOSO et al. (2001b), quando elevaram a concentração de todos macronutrientes conjuntamente até $100 \%$ daquela do meio de cultura MS.

\section{AGRADECIMENTOS \\ À FAPERGS, CAPES e FIPE/UFSM pelo finan- ciamento deste trabalho.}

\section{REFERÊNCIASBIBLIOGRÁFICAS}

AVILA, A. de L.; PEREYRA, S.M.; ARGUELLO, J.A. Nitrogen concentration and proportion of $\mathrm{NH}_{4}{ }^{+} \mathrm{N}$ affect potato cultivar response in solid and liquid media. HortScience, Alexandria, v.33, n.2, p.336-338, 1998.

BARBAS, E. et al. Orthophosphate nutrition of in vitro propagated hybrid walnut (Juglans nigra $\mathrm{x}$ Juglans regia) trees: $\mathrm{Pi}\left({ }^{32} \mathrm{Pi}\right)$ uptake and transport in relation to callus and shoot development. Plant Physiology and Biochemistry, Paris, v.31, n.1, p.41-49, 1993.

CURTIS, W.R.; HASEGAWA, P.M.; EMERY, A.H. Modeling linear and variable growth in phosphate limited suspension cultures of oppium poppy. Biotechnology and Bioengeneering, New York, v.38, p.371-379, 1991.

DANIEL, O. et al. Aplicação de fósforo em mudas de Acacia mangium Willd. Revista Árvore, Viçosa, v.21, n.2, p.163$168,1997$.

DINIZ, J.D.N.; GONÇALVES, A.N.; MINAMI, K. Absorção de macronutrientes em explantes de bananeira cv. Prata anã in vitro. Belém, PA, 1997. In: CONGRESSO BRSILEIRO DE FISIOLOGIA VEGETAL, 6, 1997. Belém, PA. Anais... Belém: SBFV, 1997. p.128.

ERICSON, T. Growth and shoot:root ratio of seedlings in relation to nutrient availability. Plant and Soil, Dordrecht, v.168-169, p.205-214, 1995.

FREDEEN, A.L.; RAO, I.M.; TERRY, N. Influence of phosphorus nutrition on growth and carbon partitioning in Glycine max. Plant Physiology, Baltimore, v.89, p.225$230,1989$.

KHAN, P.S.S.V.; HAUSMAN, J.F.; RAO, K.R. Clonal multiplication of Syzygium alternifolium (Wight.) Walp., through mature nodal segments. Silvae Genetica, Frankfurt, v.48, n.1, p.45-50, 1999.

KUMAR, S.; SARKAR, A.K.; KUNHIKANNAN, C. Regeneration of plants from leaflet explants of tissue culture raised safed siris (Albizia procera). Plant Cell, Tissue and Organ Culture, The Hague, v.54, p.137-143, 1998.

LEIFERT, C.; MURPHY, K.; LUMSDEN, P.J. Mineral and carbohydrate nutrition of plant cell and tissue culture. Critical Reviews in Plant Sciences, Boca Raton, v.14, n.2, p.83109, 1995.

LYNCH, J.; LÄUCHLI, A.; EPSTEIN, E. Vegetative growth of the common bean in response to phosphorus nutrition. Crop Science, Madison, v.31, p.380-387, 1991. 
MARSCHNER, H. Mineral nutrition of higher plants. 2.ed. London: Academic,1995. 888p.

MONTANARI, I.Jr.; MAGALHÃES, P.M.; QUEIROGA, C.L. Influence of plantation density and cultivation cycle on root productivity and tenors of $\beta$-ecdysone in Pfaffia glomerata (Spreng) Pedersen. Acta Horticulturae, Wageningen, v.3, n.502, p.125-129, 1999 .

MORARD, P.; HENRY, M. Optimization of the mineral composition of in vitro culture media. Journal of Plant Nutrition, New York, v.21, n.8, p.1565-1576, 1998.

MORARD, P.; FULCHERI, C.; HENRY, M. Mineral nutrition of Gypsophila in vitro root culture. Journal of Plant Nutrition, New York, v.22, n.4-5, p.717-730, 1999.

MURASHIGE, T.; SKOOG, F. A revised medium for rapid growth and bioassays with tobacco tissue cultures. Physiologia Plantarum, Copenhagen, v.15, p.473-497, 1962.

NICOLOSO, F.T.; FORTUNATO, R.P.; FOGAÇA, M.A.F. Influência da posição da estaca no ramo e do substrato no enraizamento de estacas de Pfaffia glomerata. Ciência Rural, Santa Maria, v.29, n.2, p.277-283, 1999.

NICOLOSO, F.T.; CASSOL, L.F.; FORTUNATO, R.P. Comprimento da estaca de ramo no enraizamento de ginseng brasileiro (Pfaffia glomerata). Ciência Rural, Santa Maria, v.31, n.1, p.57-60, 2001a.
NICOLOSO, F.T. et al. Micropropagação do ginseng brasileiro [Pfaffia glomerata (Spreng.) Pedersen]. Revista Brasileira de Plantas Medicinais, Botucatu, v.3, n.2, p.11-18, $2001 \mathrm{~b}$.

ROBINS, R.J.; RATCLIFFE, R.G. Intracellular distribution of phosphate in cultures Humulus lupulus cells growing at elevated exogenous phosphate concentrations. Plant Cell Report, New York, v.3, p.234-236, 1984.

SARKAR, D.; NAIK, P.S. Effect of inorganic nitrogen nutrition on cytokinin-induced potato microtuber production in vitro. Potato Research, Wageningen, v.41, p.211-217, 1998.

SARTORI, J.S. Aspectos anatômicos da lâmina foliar de Pfaffia glomerata (Spreng.) Pedersen (Amaranthaceae) cultivada em diferentes condições ambientais. 2000. 52f. Monografia (Especialização em Biologia) - Curso de Pósgraduação em Biologia, Universidade Federal de Santa Maria.

SERRET, M.D. et al. The effect of different closure types, light, and sucrose concentrations on carbon isotope composition and growth of Gardenia jasminoides plantlets during micropropagation and subsequent acclimation ex vitro. Plant Cell, Tissue and Organ Culture, The Hague, v.47, n.3, p.217-230, 1997.

ZARRABEITIA, A. et al. Influence of nitrogen supply on micropropagation and subsequent microtuberization of four potato cultivars. American Potato Journal, Bangor, v.74, n.6, p.369-378, 1997. 